\title{
FACTOR AFFECTING GOOD UNIVERSITY GOVERNANCE IN FINAN- CIAL INFORMATION SYSTEM: EVIDENCE FROM UNIVERSITY OF INDONESIA
}

\author{
Rani Fariha ${ }^{1,2}$ and Ferdinand DS $^{1,2} \boldsymbol{\square}$ \\ Faculty of Administrative Science, University of Indonesia, Indonesia \\ ${ }^{2}$ Gedung Mochtar Lantai 3, Pegangsaan Timur, Cikini, Jakarta Pusat, 10310, Indonesia
}
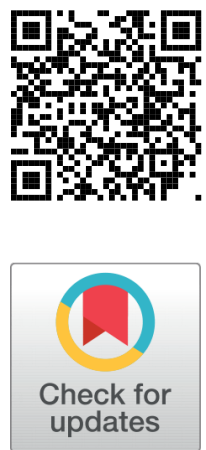

Received 4 July 2021

Accepted 22 July 2021

Published 31 July 2021

Corresponding Author

Rani Fariha, rani.f@ui.ac.id

DOI 10.29121/

granthaalayah.v9.i7.2021.4117

Funding: This research received no specific grant from any funding agency in the public, commercial, or not-for-profit sectors.

Copyright: (C) 2021 The Author(s). This is an open access article distributed under the terms of the Creative Commons Attribution License, which permits unrestricted use, distribution, and reproduction in any medium, provided the original author and source are credited.



\section{ABSTRACT}

This study aims to determine the factors that affect the realization of Good University Governance in financial information governance at the University of Indonesia. The variables used in this study are transformational leadership, system quality, information quality, service quality, individual impact, and information system user satisfaction. The approach used in this research is quantitative research. Data obtained from 94 users of financial information systems were collected through questionnaires and analyzed using partial-least squares structural equation modeling (PLS-SEM). The results show that transformational leadership and service quality have a positive effect on Good University Governance. The quality of the system and the quality of information have a positive effect on the impact of individuals, and the quality of information and the quality of service affect the satisfaction of users of financial information systems. Good University Governance can be realized by integrating the vision and mission of the organization and its leaders, human resources, and quality infrastructure. Another important thing is the monitoring, evaluation, and adaptation of these three aspects according to the needs and current developments.

Keywords: Good University Governance, Transformational Leadership, Financial Information System, Service Quality, PLS-SEM

\section{INTRODUCTION}

\section{Background}

University as a part of an education system is notably demanded to be able to deal with operational problems and a fast-changing, uncertain and tremendous global challenges. Effective and efficient governance arrangements are necessary to support the continuity organization in achieving the vision, mission and strategy Slamet 
and Yona (2015).

Information system is an important requirement for universities in enhancing Good University Governance (GUG) Tajuddin (2015). Such valuable information system is designed in the form of an information system that eases interested parties to access every transaction and financial report which is one form of delivering information to the public. The administrative operator shall optimize the provision of the required information. Based on the law, it is stated that public information is any news related to the organizer that is produced, stored, managed, sent, and or received by a public agency (Undang-undang 14/2008:1).

The presentation of such formulated information is contained in indispensable financial reports as a form of transparency and accountability in accounting management. With regard to this issue. Nordiawan (2010) stated that the information delivery to entities that as a whole makes the financial system of the agency transparent and accountable. Accessibility of financial reports included in the function of Good University Governance (GUG), can be in the form of reports that have been compiled and published or can be accessed through a computerized system created by an institution for the sake of convenience and speed of receiving financial data that has been carried out and will be carried out for planning next accounting.

The University of Indonesia through Majelis Wali Amanatnya in 2015 has issued regulations containing Anggaran Rumah Tangga and Pedoman Pengelolaan Keuangan in University of Indonesia carried out in an orderly manner and in accordance with the provisions addressed by the Central Government and prepared university regulations, thus the GUG could be conducted smoothly. The financial integration system at the University level which makes financial management at the University of Indonesia is carried out on the University Administration Center. Furthermore, planning, allocation, distribution and utilization of the budget are accomplished at the University level with a governance system regulated by the University Administration Center in jointly procedures determined on the Standard Operating Procedures (SOP).

The integration system created by the University uses manual and computerized financial management systems and procedures, carried out in accordance with the financial management cycle or stages that take into account standard procedures agreed based on the prepared Standar Biaya Keluaran. The centralized system compiled by the University allows the University to manage accounting received from various income sources such as Dana Masyarakat Dana Pemerintah (DIPA), as well as other funds received by the University as a result of collaboration or other activities.

In this regard, an integrated financial information system is the development of several systems used under one umbrella. This system is expected to seek assistance on entities to be able to recognize the development of quick and accurate financial reports, so as to create transparent and accountable financial reports in one integrated system. 
As well, Desi (2017) stated that the implementation of Good Governance in universities uses several principles such as transparency, referred as clear, accurate and easily accessible information provision, independence where decision making is not affected by any interests and all influences and pressure, accountability in which the division implementation upon tasks and responsibilities in accordance with its the main functions as well as in accordance with the vision, mission and main indicators of the university, accountability (responsibility) by publicly submitting financial reports.

This study adopted varied approaches to the review, the DeLon and McLean method which explains the dimensions that affect an outcome system developed by Tajuddin (2015) which combines supporting variables in an effort to establish user satisfaction and the impact of individuals on the success of a system. These variables are transformational leadership, system quality, information quality, service quality, user satisfaction, and individual impact in the achievement of Good University Governance (GUG) implementation.

\section{Good University Governance}

Governance in higher education is the means by which institutions for higher education are formally organized and managed its own affairs both in form and process Shattock (2006). Therefore, as a theoretical matter, Carnagie (2009) stated that governance is a combination of policies and procedures used in making decisions in effective organizational management. The concept used in the management of higher education which is currently the guideline is the application of Good University Governance (GUG). The basis for the emergence of the GUG discourse in the administration of higher education according to Wijatno (2009) GUG can be seen as the application of the basic principles of the concept of "good governance". An effective organization runs like a well-designed if the governance system is healthy and effective to be accountable through transparency and accountability. With a strategic role in society, public trust related to the national economy and social development has high trust, thus the concept of GUG is notably essential. GUG in higher education is not only administrative, yet it has a shared responsibility involving the participation of all college constituents.

\section{Transformational Leadership}

Transformational leadership includes three components, ideal affect (charisma), intellectual stimulation, and individual attention Avolio (1994). Transformational behavior is a new revision of the theory of transformational leadership called inspirational motivation (Bass and Avolio, 1999). The transformational leadership model has a reference as a leadership style in universities that has good validity and the system that is run proves success in terms of information quality and service quality, user satisfaction and individual impact. With regard to this issue, Pounder (2001) has developed a transformational leadership model into five sub-dimensions cited 
as follows (Rafferty, 2004): a. Vision; b. Inspirational communication; c. Supportive leadership; d. Intellectual stimulation; e. Personal confession.

\section{System Quality}

The DeLone and McLean model are references for many parties in conducting research on the system quality of either a frequent and familiar organization or institution with the name of the DeLone and McLean information system success model (D\&M is Success Model). The system quality is affected by several factors, both internal and external. These factors include: a) hardware, b) software, c) policy, and d) information system procedures.

\section{Information Quality}

Assessing the performance function of information system, it is necessary to possess good quality information, thus it can produce good information quality. According to Li et al., (2002), the information needed by users is quality, accurate, clear, relevant, and detailed information and has speed in delivering information in a timely manner and up to date information. While Mason (1978) tried to examine that the output quality of information system can be measured from the information quality. The information quality will have an impact and affect on individuals. Information systems are expected to have a positive impact, improving the ability to make decisions, effective working, and the job quality Delone and Mclean (2003).

\section{Service Quality}

The quality of information system services concerns to the system quality produced, whether the user is willing, the extent to which the system can assist users in producing work. The service quality variable will be measured Delone and Mclean (2004) through the following indicators: a. Quick response; b. Insurance; c. Empathy; d. Follow up; e. Online effectiveness.

\section{Individual Impact}

Individual impact can be affected because of the transformational leadership. The high value of transformational leadership is proportional to the value of the individual impact. The affect of information from the individual impact on user behavior is closely related to improving the performance of each user of the system. With regard to this issue, Mason (1978) described the sequence of individual impacts, starting from receiving information, understanding information, changing decision behavior, and applying certain information to bring about changes in organizational performance. Individual impact has a significant contribution impact to users, called as a better understanding of decision making to increase the productivity of information systems. Variables of individual impact Goodhue (1998) are: a. Effectiveness and productivity; b. Important and valuable. 


\section{Research Hypothesis}

H1. Transformational leadership has a positive effect on individual impact

H2. Transformational leadership has a positive effect on user satisfaction

H3. Transformational leadership has a positive effect on good university governance

H4. System quality has a positive effect on individual impact

H5. System quality has a positive effect on user satisfaction

H6. System quality has a positive effect on good university governance

H7. Information quality has a positive effect on individual impact

H8. Information quality has a positive effect on user satisfaction

H9. Information quality has a positive effect on good university governance

H10. Service quality has a positive effect on individual impact

H11. Service quality has a positive effect on user satisfaction

H12. Service quality has a positive effect on good university governance

H13. Individual impact has a positive effect on user satisfaction

H14. Individual impact has a positive effect on good university governance

H15. User satisfaction has a positive effect on good university governance

\section{MATERIALS AND METHODS}

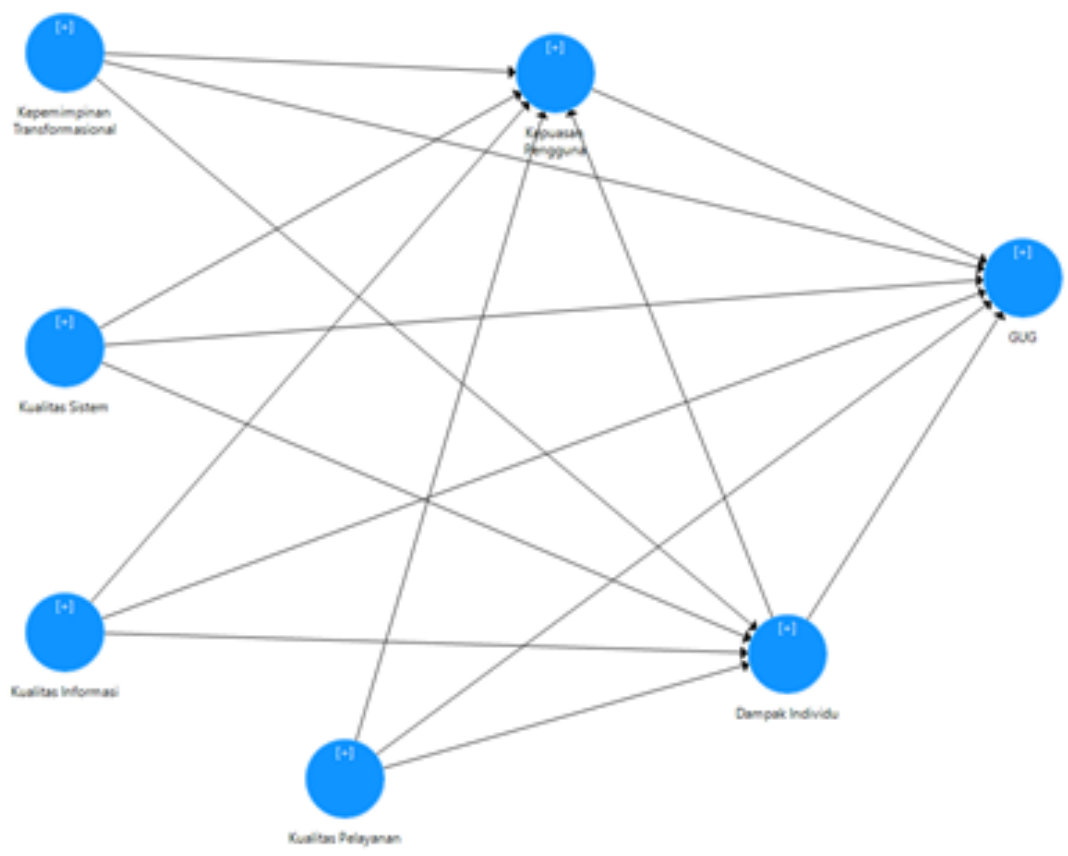

Figure 1 Research Model Framework 
This study uses a quantitative approach with the object of research is the user of the financial management information system at the University of Indonesia. The research sample was selected using non-probability sampling, namely purposive sampling.

The research model framework is presented in Figure 1 which consists of the variables of transformational leadership, system quality, information quality, service quality, individual impact, user satisfaction, and good university governance. This study focuses on knowing the effect of transformational leadership, system quality, information quality, service quality, individual impact, and user satisfaction on good university governance.

Research variables were measured using measurement indicators with 5 Likert scales, namely (1) strongly disagree, (2) disagree, (3) neutral, (4) agree, and (5) strongly agree. Another variable that was also studied was the demographics of the respondents consisting of gender, age, and long working experience. Data was collected using an online questionnaire. Research variables and indicators are presented in the following table.

\begin{tabular}{|c|c|c|}
\hline Variable & Indicator & \\
\hline \multirow{7}{*}{$\begin{array}{l}\text { Transformational } \\
\text { leadership (KT) }\end{array}$} & KT1 & Leaders have a clear, directed and measurable vision \\
\hline & KT2 & Leaders grow my confidence in doing work \\
\hline & KT3 & Leaders can motivate the team to work better \\
\hline & KT4 & Leaders awakens my enthusiasm for doing the job \\
\hline & KT5 & $\begin{array}{l}\text { Leaders encourage me to always be innovative in getting } \\
\text { work done }\end{array}$ \\
\hline & KT6 & Leaders provide feedback or responses to what I do \\
\hline & KT7 & $\begin{array}{l}\text { Leaders treat employees as individuals who each have } \\
\text { needs, abilities, and aspirations }\end{array}$ \\
\hline \multirow[t]{8}{*}{ System quality (KS) } & KS1 & $\begin{array}{l}\text { The financial information system is very easy to use by } \\
\text { every financial management entity (leadership and staff) }\end{array}$ \\
\hline & KS2 & $\begin{array}{l}\text { Available systems can be easily integrated with other } \\
\text { related systems }\end{array}$ \\
\hline & KS3 & $\begin{array}{l}\text { The system can be continuously developed according to } \\
\text { user needs }\end{array}$ \\
\hline & KS4 & $\begin{array}{l}\text { Financial reports are easily accessed to find out daily, } \\
\text { weekly and period financial updates }\end{array}$ \\
\hline & KS5 & $\begin{array}{l}\text { The financial information system has updated data } \\
\text { accuracy }\end{array}$ \\
\hline & KS6 & $\begin{array}{l}\text { System repairs are carried out quickly if an error occurs } \\
\text { in the software system }\end{array}$ \\
\hline & KS7 & $\begin{array}{l}\text { The existing financial information system makes it easier } \\
\text { for leaders to make decisions }\end{array}$ \\
\hline & KS8 & $\begin{array}{l}\text { The system is made in a technological language that is } \\
\text { easy to understand }\end{array}$ \\
\hline $\begin{array}{l}\text { Information quality } \\
\qquad(\mathrm{KI})\end{array}$ & KI1 & $\begin{array}{l}\text { The information available in the financial information } \\
\text { system has met the needs of users }\end{array}$ \\
\hline
\end{tabular}




\begin{tabular}{|c|c|c|}
\hline Table 1 continued & & \\
\hline & KI2 & $\begin{array}{l}\text { The financial information system provides precise and } \\
\text { accurate information }\end{array}$ \\
\hline & KI3 & The financial information system that I use is easy to use \\
\hline & KI4 & $\begin{array}{l}\text { The information systems available now meet financial } \\
\text { governance kelola }\end{array}$ \\
\hline & KI5 & $\begin{array}{l}\text { I believe that this financial information system makes my } \\
\text { job easier }\end{array}$ \\
\hline & KI6 & $\begin{array}{l}\text { I easily understand every financial related thing } \\
\text { provided in the financial information system sistem }\end{array}$ \\
\hline \multirow[t]{5}{*}{ Service quality (KP) } & KP1 & $\begin{array}{l}\text { Financial information system services provided in } \\
\text { accordance with the agreement/procedure provided }\end{array}$ \\
\hline & KP2 & $\begin{array}{c}\text { Financial information system services provided } \\
\text { according to the time and timeline provided }\end{array}$ \\
\hline & KP3 & $\begin{array}{l}\text { The financial information system services provided are } \\
\text { carried out quickly and with the right response }\end{array}$ \\
\hline & KP4 & $\begin{array}{l}\text { Available financial information system services in } \\
\text { accordance with the needs and interests of users }\end{array}$ \\
\hline & KP5 & $\begin{array}{c}\text { Financial information system services have a good } \\
\text { appearance and are easy to understand }\end{array}$ \\
\hline \multirow[t]{4}{*}{$\begin{array}{l}\text { User satisfaction } \\
\qquad(\mathrm{KPP})\end{array}$} & KPP1 & $\begin{array}{l}\text { The quality of the financial information system } \\
\text { (software) is very good and helps the job }\end{array}$ \\
\hline & KPP2 & $\begin{array}{c}\text { The quality of the integrated system will make work } \\
\text { easier and time more efficient }\end{array}$ \\
\hline & KPP3 & $\begin{array}{l}\text { I am satisfied with the financial information system } \\
\text { software so that it becomes effective for improving the } \\
\text { financial system }\end{array}$ \\
\hline & КРP4 & $\begin{array}{l}\text { I am satisfied with the quality of the financial } \\
\text { information system (software) }\end{array}$ \\
\hline \multirow[t]{4}{*}{$\begin{array}{l}\text { Individual impact } \\
\qquad \text { (DI) }\end{array}$} & DI1 & $\begin{array}{l}\text { The financial information/service system created makes } \\
\text { my work more effective }\end{array}$ \\
\hline & DI2 & $\begin{array}{l}\text { Information systems/financial services make users more } \\
\text { productive }\end{array}$ \\
\hline & DI3 & $\begin{array}{l}\text { Information systems/financial governance services } \\
\text { provide confidence for every user }\end{array}$ \\
\hline & DI4 & $\begin{array}{l}\text { Information systems/financial services provide } \\
\text { knowledge and understanding for me regarding good } \\
\text { financial management }\end{array}$ \\
\hline \multirow[t]{5}{*}{$\begin{array}{l}\text { Good University } \\
\text { Governance (GUG) }\end{array}$} & GUG1 & $\begin{array}{l}\text { Financial management is carried out transparently to the } \\
\text { entire community }\end{array}$ \\
\hline & GUG2 & $\begin{array}{l}\text { Financial management and reporting is carried out in } \\
\text { accordance with accounting procedures and standards }\end{array}$ \\
\hline & GUG3 & $\begin{array}{l}\text { Financial management on campus is carried out } \\
\text { independently for the benefit of the campus and not for } \\
\text { personal interests }\end{array}$ \\
\hline & GUG4 & $\begin{array}{l}\text { The financial administration process is carried out by } \\
\text { taking into account the fairness of each transaction and } \\
\text { remains in accordance with }\end{array}$ \\
\hline & GUG5 & $\begin{array}{l}\text { Integrated financial management that makes work more } \\
\text { effective }\end{array}$ \\
\hline
\end{tabular}




\section{RESULTS AND DISCUSSIONS}

The total sample of this study amounted to 94 respondents who have different demographic characteristics. The demographic characteristics of the respondents are presented in Table 2 which is divided into 3 variables, namely gender, age, and long experience working at the University of Indonesia.

\begin{tabular}{|ccc|}
\hline \multicolumn{2}{l}{ Table 2 Respondent Demographics } \\
\hline Demographics & Frequency & Percentage (\%) \\
Gender & & \\
Man & 26 & 27.7 \\
Woman & 68 & 72.3 \\
\hline Ages & & \\
\hline $21-30$ & 27 & 28.7 \\
31-40 & 37 & 39.4 \\
\hline $41-50$ & 23 & 24.5 \\
\hline Above 50 & 7 & 7.4 \\
\hline Work Experience & & \\
\hline 1-5 years & 30 & 31.9 \\
\hline 5-10 yearcs & 21 & 22.3 \\
\hline Above 10 years & 43 & 45.7 \\
\hline
\end{tabular}

Based on the table of demographic characteristics of respondents, there are $27.7 \%$ of respondents are male and $72.3 \%$ are female. The age of respondents consists of 4 categories with each percentage: $28.7 \%$ of respondents aged $21-30$ years, $39.4 \%$ aged $31-40$ years, $24.5 \%$ aged $41-50$ years, and only $7.4 \%$ of respondents aged over 50 years. The respondents' long working experience was divided into 3 categories: $31.9 \%$ 1-5 years, $22.3 \%$ 5-10 years, and $45.7 \%$ of respondents with more than 10 years of experience.

\section{Result}

This research uses structural equation modeling (SEM) analysis with partial-least squares (PLS-SEM) approach. Data processing is done using Smart PLS 3.3.2 software. PLS-SEM is an alternative to conventional SEM (CB-SEM) which is very suitable and effective for models that tend to be complex with relatively small samples, which are under 100 data samples Hair et al. (2011), Henseler et al. (2013), Raza et al. (2020).

PLS-SEM was used to evaluate the measurement model and the structural model. The measurement model (also known as the outer model) describes the relationship between latent variables and their indicators while the structural model (also known as the inner model) describes the relationship between latent variables Hair et al. (2017).

Evaluation of the measurement model is used as a validation of latent variable indicators. Hair et al. (2017) divides the evaluation of the measurement model into 2 
parts, namely convergent validity and discriminant validity. Hair et al. (2017) stated that convergent validity was determined by outer loading, Cronbach's alpha and Composite reliability, and Average variance extracted (AVE). The outer loading value must be above 0.4 Hair et al. (2017), Raza et al. (2018), Cronbach's alpha is above 0.55 and Composite reliability must be above 0.7 Hair et al. (2017), Tabachnick and Fidell (2007) , and AVE must have a value above 0.5 Hair et al. (2017), Fornell and Larcker (1981). There is also discriminant validity can be seen from the correlation value between latent variables which is smaller than the square root AVE and cross loading Fornell and Larcker (1981).

Table 3 Convergent Validity

\begin{tabular}{|c|c|c|c|c|c|}
\hline Variable & Indicator & Outer loading & Cronbach's alpha & Composite reliability & AVE \\
\hline \multirow[t]{4}{*}{ DI } & DI1 & 0.862 & 0.876 & 0.915 & 0.730 \\
\hline & DI2 & 0.819 & & & \\
\hline & DI3 & 0.899 & & & \\
\hline & DI4 & 0.836 & & & \\
\hline \multirow[t]{5}{*}{ GUG } & GUG1 & 0.711 & 0.854 & 0.896 & 0.633 \\
\hline & GUG2 & 0.802 & & & \\
\hline & GUG3 & 0.811 & & & \\
\hline & GUG4 & 0.872 & & & \\
\hline & GUG5 & 0.773 & & & \\
\hline \multirow[t]{6}{*}{$\mathrm{KI}$} & KI1 & 0.788 & 0.869 & 0.902 & 0.604 \\
\hline & $\mathrm{KI} 2$ & 0.793 & & & \\
\hline & $\mathrm{KI} 3$ & 0.818 & & & \\
\hline & KI4 & 0.770 & & & \\
\hline & KI5 & 0.765 & & & \\
\hline & KI6 & 0.727 & & & \\
\hline \multirow[t]{5}{*}{ KP } & KP1 & 0.751 & 0.766 & 0.839 & 0.513 \\
\hline & KP2 & 0.596 & & & \\
\hline & KP3 & 0.772 & & & \\
\hline & KP4 & 0.743 & & & \\
\hline & KP5 & 0.705 & & & \\
\hline \multirow[t]{4}{*}{ KPP } & KPP1 & 0.775 & 0.828 & 0.887 & 0.663 \\
\hline & KPP2 & 0.745 & & & \\
\hline & KPP3 & 0.885 & & & \\
\hline & KPP4 & 0.844 & & & \\
\hline \multirow[t]{8}{*}{ KS } & KS1 & 0.748 & 0.884 & 0.908 & 0.556 \\
\hline & KS2 & 0.774 & & & \\
\hline & KS3 & 0.668 & & & \\
\hline & KS4 & 0.824 & & & \\
\hline & KS5 & 0.810 & & & \\
\hline & KS6 & 0.616 & & & \\
\hline & KS7 & 0.769 & & & \\
\hline & KS8 & 0.731 & & & \\
\hline \multirow[t]{4}{*}{ KT } & KT1 & 0.769 & 0.918 & 0.935 & 0.672 \\
\hline & KT2 & 0.840 & & & \\
\hline & KT3 & 0.863 & & & \\
\hline & KT4 & 0.851 & & & \\
\hline
\end{tabular}




\section{Table 3 continued}

$\begin{array}{ll}\text { KT5 } & 0.834 \\ \text { KT6 } & 0.815 \\ \text { KT7 } & 0.761\end{array}$

Note: $\mathrm{DI}=$ Individual impact, GUG = Good University Governance, $\mathrm{KI}=$ Information quality, KP = Service quality, KPP = User satisfaction, KS = System quality, KT = Transformational leadership

Apart from being an indicator validation of latent variables, outer loading also shows how important an indicator is compared to other indicators. In the transformational leadership variable, the indicator with the highest level of importance is KT3 (Leaders can motivate the team to work better) with outer loading of 0.863 . Indicator KS4 (Easy access to financial reports to find out daily, weekly, or period financial updates) becomes the most important indicator on the system quality variable with an outer loading of 0.824 . On the information quality variable, indicator KI3 (the financial information system I use is easy to use) has the highest outer loading of 0.818 . The KP3 indicator (financial information system services provided is carried out quickly and with the right response) is the indicator with the highest level of importance on the service quality variable with an outer loading of 0.772 . In the individual impact variable, the DI3 indicator (Information systems/financial governance services provide confidence for each user) has the highest outer loading of 0.899. In the user satisfaction variable, the KPP3 indicator (I am satisfied with the financial information system software so that it becomes effective for improving the work system) has the highest outer loading with a value of 0.885 . As for the GUG variable, the most important indicator with an outer loading of 0.872 is GUG4 (the financial administration process is carried out by taking into account the fairness of each transaction and remains in accordance with the provisions of existing regulations).

Table 4 Cross loading

\begin{tabular}{cccccccc}
\hline Indikator & DI & GUG & KI & KP & KPP & KS & KT \\
\hline DI1 & 0.862 & 0.522 & 0.763 & 0.636 & 0.738 & 0.652 & 0.364 \\
\hline DI2 & 0.819 & 0.396 & 0.772 & 0.603 & 0.749 & 0.647 & 0.323 \\
DI3 & 0.899 & 0.494 & 0.774 & 0.596 & 0.678 & 0.677 & 0.395 \\
\hline DI4 & 0.836 & 0.560 & 0.676 & 0.571 & 0.661 & 0.663 & 0.458 \\
\hline GUG1 & 0.438 & 0.711 & 0.375 & 0.376 & 0.313 & 0.414 & 0.304 \\
\hline GUG2 & 0.406 & 0.802 & 0.394 & 0.401 & 0.426 & 0.398 & 0.403 \\
\hline GUG3 & 0.336 & 0.811 & 0.320 & 0.485 & 0.392 & 0.390 & 0.407 \\
\hline GUG4 & 0.445 & 0.872 & 0.453 & 0.484 & 0.461 & 0.482 & 0.501 \\
GUG5 & 0.637 & 0.773 & 0.559 & 0.491 & 0.618 & 0.577 & 0.376 \\
\hline KI1 & 0.660 & 0.466 & 0.788 & 0.542 & 0.681 & 0.610 & 0.317 \\
\hline KI2 & 0.696 & 0.425 & 0.793 & 0.624 & 0.712 & 0.694 & 0.313 \\
\hline KI3 & 0.659 & 0.262 & 0.818 & 0.603 & 0.700 & 0.514 & 0.139 \\
\hline KI4 & 0.592 & 0.322 & 0.770 & 0.581 & 0.657 & 0.473 & 0.261 \\
\hline KI5 & 0.716 & 0.517 & 0.765 & 0.613 & 0.723 & 0.625 & 0.352 \\
\hline KI6 & 0.734 & 0.478 & 0.727 & 0.600 & 0.625 & 0.654 & 0.350 \\
\hline
\end{tabular}




\begin{tabular}{|c|c|c|c|c|c|c|c|}
\hline \multicolumn{8}{|c|}{ Table 4 continued } \\
\hline KP1 & 0.502 & 0.611 & 0.513 & 0.751 & 0.579 & 0.533 & 0.446 \\
\hline KP2 & 0.278 & 0.293 & 0.200 & 0.596 & 0.208 & 0.144 & 0.166 \\
\hline KP3 & 0.542 & 0.470 & 0.506 & 0.772 & 0.444 & 0.433 & 0.340 \\
\hline KP4 & 0.591 & 0.349 & 0.719 & 0.743 & 0.677 & 0.540 & 0.192 \\
\hline KP5 & 0.530 & 0.263 & 0.660 & 0.705 & 0.619 & 0.447 & 0.141 \\
\hline KPP1 & 0.588 & 0.531 & 0.602 & 0.583 & 0.775 & 0.629 & 0.328 \\
\hline KPP2 & 0.650 & 0.583 & 0.598 & 0.512 & 0.745 & 0.607 & 0.397 \\
\hline KPP3 & 0.737 & 0.401 & 0.839 & 0.672 & 0.885 & 0.592 & 0.298 \\
\hline KPP4 & 0.712 & 0.344 & 0.816 & 0.653 & 0.844 & 0.566 & 0.248 \\
\hline KS1 & 0.524 & 0.500 & 0.491 & 0.412 & 0.458 & 0.748 & 0.384 \\
\hline KS2 & 0.496 & 0.312 & 0.571 & 0.455 & 0.542 & 0.774 & 0.256 \\
\hline KS3 & 0.590 & 0.289 & 0.617 & 0.479 & 0.581 & 0.668 & 0.267 \\
\hline KS4 & 0.629 & 0.423 & 0.594 & 0.458 & 0.553 & 0.824 & 0.355 \\
\hline KS5 & 0.654 & 0.460 & 0.605 & 0.494 & 0.576 & 0.810 & 0.394 \\
\hline KS6 & 0.465 & 0.351 & 0.513 & 0.534 & 0.492 & 0.616 & 0.329 \\
\hline KS7 & 0.646 & 0.588 & 0.612 & 0.385 & 0.560 & 0.769 & 0.563 \\
\hline KS8 & 0.560 & 0.464 & 0.582 & 0.522 & 0.606 & 0.731 & 0.281 \\
\hline KT1 & 0.368 & 0.495 & 0.298 & 0.300 & 0.312 & 0.473 & 0.769 \\
\hline KT2 & 0.439 & 0.501 & 0.310 & 0.263 & 0.356 & 0.472 & 0.840 \\
\hline KT3 & 0.289 & 0.333 & 0.202 & 0.215 & 0.246 & 0.318 & 0.863 \\
\hline KT4 & 0.382 & 0.395 & 0.318 & 0.331 & 0.330 & 0.346 & 0.851 \\
\hline KT5 & 0.358 & 0.420 & 0.363 & 0.373 & 0.361 & 0.372 & 0.834 \\
\hline KT6 & 0.338 & 0.355 & 0.309 & 0.280 & 0.256 & 0.379 & 0.815 \\
\hline KT7 & 0.372 & 0.344 & 0.335 & 0.351 & 0.342 & 0.359 & 0.761 \\
\hline
\end{tabular}

Table 5 Fornell-Larcker - Discriminant Validity

\begin{tabular}{cccccccc}
\hline & \multicolumn{7}{c}{ Correlation Matrix } \\
\hline & DI & GUG & KT & KPP & KI & KP & KS \\
\hline DI & 0.854 & & & & & \\
GUG & 0.577 & 0.795 & & & & \\
KT & 0.450 & 0.505 & 0.820 & & & \\
KPP & 0.828 & 0.569 & 0.390 & 0.814 & & \\
KI & 0.874 & 0.537 & 0.376 & 0.881 & 0.777 & & \\
KP & 0.705 & 0.568 & 0.371 & 0.745 & 0.765 & 0.716 & \\
\hline KS & 0.772 & 0.576 & 0.482 & 0.735 & 0.772 & 0.624 & 0.745 \\
\hline
\end{tabular}

Note: $\mathrm{DI}=$ Individual impact, GUG = Good University Governance, KI = Information quality, KP = Service quality, KPP = User satisfaction, KS = System quality, KT = Transformational leadership The diagonal of the matrix is the square root of AVE (average variance extracted)

Evaluation of the structural model is used to measure the goodness of fit based on the value of $\mathrm{R}^{2}$ (R-square) and to test the significance of the effect of the independent variable on the dependent variable or known as hypothesis testing Hair et al. (2017), (Rigdon, 2012). R2 is the coefficient of determination that describes the strength and the extent to which the variance of the dependent variable can be explained by the independent variable. The value of $\mathrm{R}^{2}$ is in the $0-1$ interval where the higher $\mathrm{R}^{2}$, the better the model. $\mathrm{R}^{2}$ values of $0.75,0.50$, and 0.25 respectively represent substantial, moderate, and weak categories Hair et al. (2011), Henseler et al. (2009). There is also 


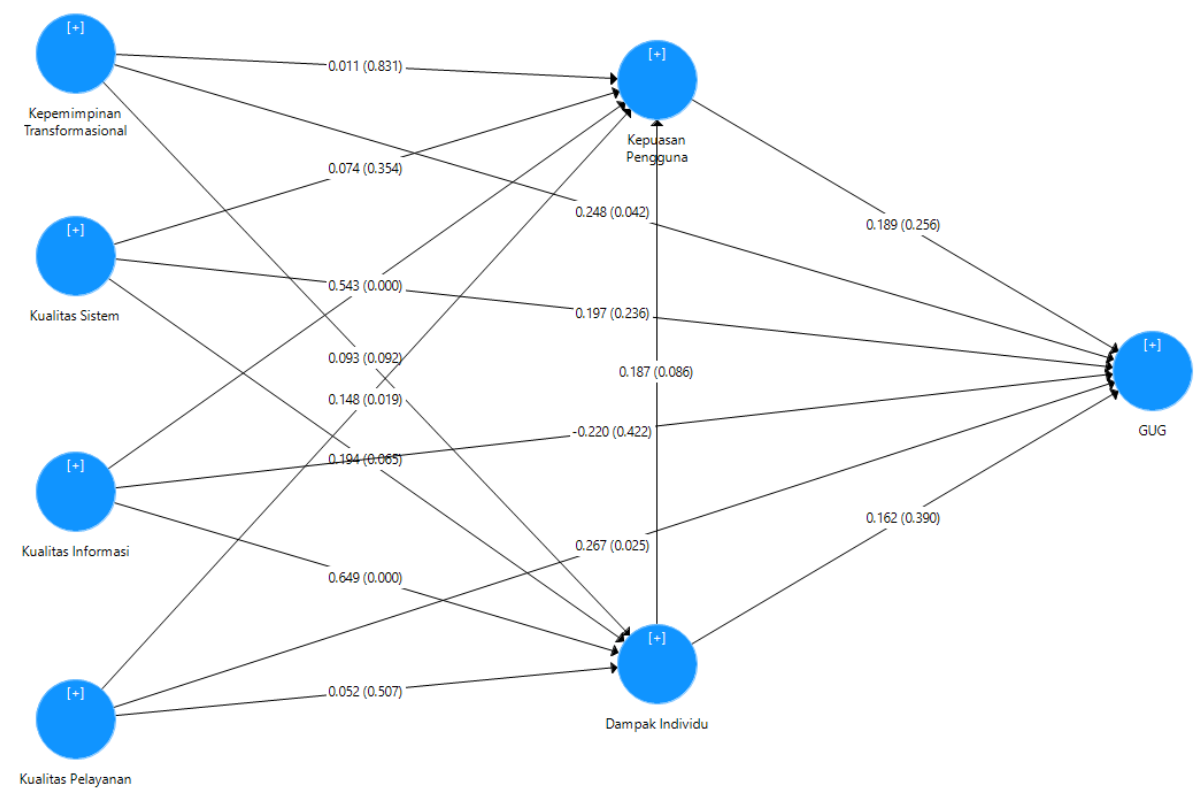

Figure 2 PLS-SEM Result

a test of the significance of the effect of the independent variable on the dependent variable seen from the $\mathrm{p}$ value which is smaller than the significance level $(\mathrm{p}<\alpha)$.

resents the $\mathrm{R}^{2}$ values for each of the dependent variables Individual impact, user satisfaction, and GUG. The individual impact has an $\mathrm{R}^{2}$ value of 0.796 , meaning that the variance of the individual impact can be explained by the independent variables: transformational leadership, system quality, information quality, and service quality by $79.6 \%$ and another $20.4 \%$ explained by other variables. User satisfaction has an $\mathrm{R}^{2}$ value of 0.802 which indicates that the independent variable can explain the variance of user satisfaction of $80.2 \%$ and the remaining $19.8 \%$ is explained by other variables not examined. GUG has an $\mathrm{R}^{2}$ of 0.473 , meaning that the variables of transformational leadership, system quality, information quality, service quality, individual impact, and user satisfaction are only able to explain the variance of GUG by $47.3 \%$.

\begin{tabular}{cc}
\hline Table 6 Goodness of Fit \\
\hline Endogenous Variable & $\mathbf{R}^{2}$ \\
\hline Individual Impact & 0.796 \\
\hline User Satisfaction & 0.802 \\
\hline Good University Governance & 0.473 \\
\hline
\end{tabular}


Table 7 Structural Model Evaluation

\begin{tabular}{cccc}
\hline Hypothesis & Effect & Coefficient & Conclusion \\
H1 & KT $\rightarrow$ DI & 0.093 & Not significant \\
H2 & KT $\rightarrow$ KPP & 0.011 & Not significant \\
H3 & KT $\rightarrow$ GUG & $0.248^{* * *}$ & Significant \\
H4 & KS $\rightarrow$ DI & $0.194^{* *}$ & Significant \\
H5 & KS $\rightarrow$ KPP & 0.074 & Not significant \\
H6 & KS $\rightarrow$ GUG & 0.197 & Not significant \\
H7 & KI $\rightarrow$ DI & $0.650^{* * *}$ & Significant \\
H8 & KI $\rightarrow$ KPP & $0.543^{* * *}$ & Significant \\
H9 & KI $\rightarrow$ GUG & -0.220 & Not significant \\
H10 & KP $\rightarrow$ DI & 0.052 & Not significant \\
\hline H11 & KP $\rightarrow$ KPP & $0.148^{* * *}$ & Significant \\
\hline H12 & KP $\rightarrow$ GUG & $0.267^{* * *}$ & Significant \\
H13 & DI $\rightarrow$ KPP & 0.187 & Not significant \\
\hline H14 & DI $\rightarrow$ GUG & 0.162 & Not significant \\
\hline H15 & KPP $\rightarrow$ GUG & 0.189 & Not significant \\
\hline
\end{tabular}

Note: $\mathrm{DI}=$ Individual impact, GUG $=$ Good University Governance, $\mathrm{KI}=$ Information quality, $\mathrm{KP}=$ Service quality, $\mathrm{KPP}=$ User satisfaction, $\mathrm{KS}=$ System quality, $\mathrm{KT}=$ Transformational leader$\operatorname{ship~}^{* * *} \mathrm{p}<0.05,{ }^{* *} \mathrm{p}<0.10$

\section{Discussion}

The hypothesis testing in Table 7 is a statistical significance test of the effect of the independent variables on the dependent variables. The effect of the transformational leadership variable (KT) on the individual impact (DI) described by H1 is not significant $(0.0=0.093, p>0.05)$. This shows that transformational leadership style has no effect on individual impact. The effect of transformational leadership variable (KT) on user satisfaction (KPP) described by H2 is not significant $(\beta=0.011, \mathrm{p}>0.05)$. The effect of transformational leadership (KT) on Good University Governance (GUG) as described by $\mathrm{H} 3$ is significant $(\beta=0.248, \mathrm{p}<0.05$ ). Transformational leadership has a positive influence on GUG, this shows that to realize GUG, transformational leadership is needed.

The effect of the system quality variable (KS) on the individual impact (DI) described by $\mathrm{H} 4$ is significant $(\beta=0.194, \mathrm{p}<0.05)$. The quality of the system has a positive influence on individual impact, the better the quality of the system, the individual will feel a better impact on self-development. The effect of the system quality variable (KS) on user satisfaction (KPP) described by $\mathrm{H} 5$ is not significant ( $\beta$ $=0.074, \mathrm{p}>0.05$ ). The effect of the system quality variable (KS) on Good University Governance (GUG) described by H6 is not significant ( $\beta=0.197, \mathrm{p}>0.05$ ).

The effect of the information quality variable (KI) on the individual impact (DI) described by $\mathrm{H} 7$ is significant $(\beta=0.650, \mathrm{p}<0.05)$. The quality of information has a positive influence on the impact of individuals, the better the quality of information, the individuals will feel a better impact on self-development. Information quality is 
also the variable with the largest significant effect on individual impact. The effect of the information quality variable (KI) on user satisfaction (KPP) described by H8 is significant $(\beta=0.543, \mathrm{p}<0.05)$. The quality of information has a positive influence on user satisfaction and becomes the variable with the greatest influence on user satisfaction. These results are in line with the research conducted by Hidayatullah et al. (2020), Delone and Mclean (2004), Rachmawati et al. (2019), Mardiana et al. (2015). The effect of the Information Quality (KI) variable on Good University Governance (GUG) described by $\mathrm{H} 9$ is not significant $(\beta=-0.220, \mathrm{p}>0.05)$.

The effect of the service quality variable (KP) on the individual impact (DI) described by $\mathrm{H} 10$ is significant $(\beta=0.052, \mathrm{p}>0.05)$. The effect of service quality variable (KP) on user satisfaction (KPP) described by H11 is significant ( $\beta=0.148$, p $<0.05)$. Service quality has a positive influence on user satisfaction, meaning that the better the quality of service provided, the more user satisfaction will increase. These results are in line with the research conducted by Hidayatullah et al. (2020), Delone and Mclean (2004), Ojo (2017). The effect of the service quality variable (KP) on Good University Governance (GUG) described by H12 is significant $(\beta=0.267$, p < $0.05)$. Service quality (KP) has a positive influence on GUG, the better and optimal service quality will encourage the realization of GUG.

The effect of the individual impact variable (DI) on user satisfaction (KPP) described by $\mathrm{H} 13$ is not significant $(\beta=0.187, \mathrm{p}>0.05)$. The effect of the individual impact variable (DI) on Good University Governance (GUG) described by H14 is not significant $(\beta=0.162, \mathrm{p}>0.05)$. There is also the effect of the variable User satisfaction (KPP) on Good University Governance (GUG) described by H15 is also not significant $(\beta=0.189, \mathrm{p}>0.05)$.

\section{CONCLUSIONS AND IMPLICATION}

This study aims to determine the factors that influence the realization of Good University Governance (GUG) in the financial information governance system at the University of Indonesia. The research sample consisted of 94 users of the financial information governance system. The independent variables in this study are transformational leadership, system quality, information quality, service quality, individual impact, and user satisfaction, while the dependent variable is Good University Governance (GUG). The results showed that system quality and information quality had a positive effect on individual impact, information quality and service quality had a positive effect on user satisfaction, and transformational leadership and service quality had a positive effect on Good University Governance (GUG).

Transformational leadership has a very important role to realize Good University Governance because in an organization the leader must have a clear vision and mission. The vision and mission of a leader must be in harmony with the organization and must also be adaptive to the times so that the transformational leadership style must be a strong foundation. Leaders are expected to be able to convey, understand, 
coordinate, and motivate each member to be able to make a positive contribution to the organization in order to realize Good University Governance.

Every member of the organization who has been able to understand the vision and mission of the organization as well as the leader will implement it in every activity that is his responsibility. This will make the organization's services better and more excellent and have a positive impact on Good University Governance. For this reason, it is important for organizations to implement key activities and monitor and evaluate regularly every activity and achievement expected by the organization for the realization of Good University Governance.

In addition, monitoring and evaluating the performance of organizational members or human resources (HR) is not enough to realize Good University Governance, but must also be accompanied by infrastructure performance in the form of systems and information. The quality of the financial information governance system and information must meet the applicable standards and must be continuously updated with the latest standards. When the quality of the system and information is guaranteed, the next step is to make the system and information on financial governance as easy as possible to be accessed by members of the organization and people who have an interest in financial information. Ease of access to systems and information is also necessary to present data and information in real-time as a form of accountability and transparency in the management of financial information to realize Good University Governance.

Good University Governance can be realized by integrating the vision and mission of the organization and its leaders, the support and quality of its resources, both human and infrastructure, as well as monitoring and evaluation processes that are carried out regularly and adaptively.

\section{REFERENCES}

Anwar, M., \& Pratolo, D. S. (2012). Penerapan Model Tata Kelola Keuangan Perguruan Tinggi Yang Baik Untuk Mewujudkan Good University Governance (Studi Pada Ptm SeIndonesia). Www.Repositoryumy.Com?Jaiumy/Pdf/Misbah.Pdf Diakses Pada Tanggal.

Avolio, B. . (1994). Improving Organizational Effectiveness Through Transformational Leadership. London: Sage Publications.

Carnagie, G. D. (2009). The Abc Of University Governance. Campus Review., 19(9).

Delone, W. H., \& Mclean, E. R. (2003). The Delone And Mclean Model Of Information Systems Success: A Ten-Year Update. Journal of Management Information Systems, 19(4), 9-30.

Delone, W. H., \& Mclean, E. R. (2004). Measuring E-Commerce Success: Applying The Delone And Mclean Information Systems Success Model. International Journal Of Electronic Commerce, 9(1), 31-47.

Fornell, C., \& Larcker, D. F. (1981). Evaluating Structural Equation Models With Unobservable Variables And Measurement Error. Journal Of Marketing Research, 18(1), 39-50.

Goodhue, D. (1998). Pengembangan Dan Pengukuran Validitas Instrumen Fit Task Technology Untuk Pengguna Evaluasi Sistem Informasi. Ilmu Keputusan, 29(1), 105-138.

Hair, J. F., Hult, G. T. M., Ringle, C. M., \& Sarstedt, M. (2017). A Primer On Partial Least Squares 
Structural Equation Modeling (Pls-Sem). Los Angeles: Sage.

Hair, J. F., Ringle, C. M., \& Sarstedt, M. (2011). Pls-Sem: Indeed A Silver Bullet. Journal Of Marketing Theory And Practice, 19(2), 139-152.

Henseler, J., Dijkstra, T. K., Sarstedt, M., Ringle, C. M., Diamantopoulos, A., Straub, D. W., Ketchen, D. J., Hair, J. F., Hult, G. T. M., \& Calantone, R. J. (2013). Common Beliefs And Reality About Pls: Comments On Ronkko And Evermann (2013). Organizational Research Methods., 17(2), 182-209.

Henseler, J., Ringle, C. M., \& Sinkovics, R. R. (2009). The Use Of Partial Least Squares Path Modeling In International Marketing. Advances In International Marketing, 20, 277-320.

Hidayatullah, S., Khouroh, U., Windhyastiti, I., Patalo, R. G., \& Waris, A. D. (2020). Implementasi Model Kesuksesan Sistem Informasi Delone And Mclean Terhadap Sistem Pembelajaran Berbasis Aplikasi Zoom Di Saat Pandemi Covid-19. Jurnal Teknologi Dan Manajemen Informatika, 6(1), 44-52.

Indonesia, R. (2008). Undang-Undang (Uu) No. 14 Tahun. Tentang Keterbukaan Informasi Publik. Lembaran Negara Ri Tahun(61).

Mardiana, S., Tjakraatmadja, J. H., \& Aprianingsih, A. (2015). Delone-Mclean Information System Success Model Revisited: The Separation Of Intention To Use - Use And The Integration Of Technology Acceptance Models. International Journal of Economics And Financial Issues.

Mason, R. (1978). Mengukur Keluaran Informasi: Pendekatan Sistem Komunikasi. Informasi \& Manajemen., 1(5), 219-234.

Nordiawan, D. (2010). Akuntansi Sektor Publik. Jakarta: Salemba Empat.

Ojo, A. I. (2017). Validation Of The Delone And Mclean Information Systems Success Model. Healthcare Informatics Research.

Peraturan Majelis Wali Amanat Universitas Indonesia Nomor 004/Peraturan/Mwaui/2015 Tentang Anggaran Rumah Tangga Universitas Indonesia. (n.d.).

Pounder, J. (2001). New Leadership And University Organizational Effectiveness: Exploring The Relationship. Leadership And Organization Development Journal, 22(6), 281-290.

Pramono, S. D. M., \& Sari. (2012). Peran Internal Audit Dalam Upaya Mewujudkan Good University Governance Di Unnes. Jurnal Dinamika Akuntansi, 4(1), 64-71.

Rachmawati, I. K., Handoko, Y., Nuryanti, F., Wulan, M., \& Hidayatullah, S. (2019). Pengaruh Kemudahan, Kepercayaan Pelanggan Dan Kualitas Informasi Terhadap Keputusan Pembelian Online. September.

Raza, S. A., Umer, A., Qazi, W., \& Makhdoom, M. (2018). The Effects Of Attitudinal, Normative, And Control Beliefs On M-Learning Adoption Among The Students Of Higher Education In Pakistan. Journal Of Educational Computing Research, 56(4), 563-588.

Raza, S. A., Umer, A., Qureshi, M. A., \& Dahri, A. S. (2020). Internet Banking Service Quality, ECustomer Satisfaction And Loyalty: The Modified E-Servqual Model. The Tqm Journal, 32(6), 1443-1466.

Shattock, M. (2006). Managing Good Governance In Higher Education. Open University Press. Slamet, H., \& Yona, I. D. (2015). Penilaian Good University Governance Pada Perguruan Tinggi Negeri Badan Layanan Umum (Studi Di Peguruan Tinggibadan Layanan Umum Di Kota Malang), Malang. Lembaga Peneltian Dan Pengabdian Kepada Masyarakat (Lp2m) Universitas Islam Negeri Maulana Malik Ibrahim, Malang..

Tabachnick, B. G., \& Fidell, L. S. (2007). Multivariate Analysis Of Variance And Covariance. Using Multivariate Statistics, 3, 402-407.

Tajuddin, M. (2015). Modification Of Delon And Mclean Model In The Success Of Information System For Good University Governance. Mataram: College Of Informatics Management 
And Computer (Stmik) Bumi Gora, Mataram Of Indonesia..

Wijatno, S. (2009). Management Of Higher Education Efficient, Effective And Economical To Improve Education Implementation And Quality Of Graduates. Salemba Empat. 